\title{
PENGARUH RETURN ON EQUITY DAN DEBT TO EQUITY RATIO TERHADAP HARGA SAHAM PADA PERUSAHAAN SUB SEKTOR PERDAGANGAN BESAR
}

\author{
K.A. Sugitajaya ${ }^{1}$, G.P.A.J. Susila ${ }^{2}$, R. Atidira ${ }^{3}$ \\ 1,2,3 Jurusan Manajemen, Universitas Pendidikan Ganesha, Singaraja. \\ e-mail:kadekarif98@gmail.com, agus.jana@undiksha.ac.id, janos_undiksha@yahoo.com, \\ rahutama.atidira@undiksha.ac.id
}

\begin{abstract}
Abstrak
Penelitian ini bertujuan untuk menguji pengaruh return on equity dan rasio hutang terhadap ekuitas terhadap harga saham, baik secara simultan maupun parsial. Desain penelitian kuantitatif kausal digunakan dalam penelitian ini. Subjek penelitian ini adalah perusahaan sub-sektor perdagangan besar yang terdaftar di Bursa Efek Indonesia, dan objek penelitian ini adalah return on equity, debt to equity ratio operasi dan harga saham. Data dikumpulkan dengan mengumpulkan dokumen dan dianalisis dengan analisis regresi linier berganda. Hasil penelitian menunjukkan bahwa 1) return on equity dan debt to equity ratio seluruhnya memiliki pengaruh signifikan terhadap harga saham, 2) return on equity secara parsial berpengaruh positif dan signifikan terhadap harga saham, 3) debt to equity ratio secara pasial berpengaruh negatif dan signifikan terhadap harga saham pada perusahaan sub-sektor perdagangan besar di Indonesia Bursa Efek.
\end{abstract}

Kata Kunci: debt to equity ratio, harga saham, return on equity

\begin{abstract}
This study aims to examine the effect of return on equity and the ratio of debt to equity on stock prices, both simultaneously and partially. Causal quantitative research designs are used in this study. The subject of this research is a large trading sub-sector company listed on the Indonesia Stock Exchange, and the object of this research is return on equity, debt to equity ratio of operations and stock prices. Data is collected by collecting documents and analyzed by multiple linear regression analysis. The results showed that 1 ) return on equity and debt to equity ratio all have a significant effect on stock prices, 2) return on equity partially has a positive and significant effect on stock prices, 3 ) debt to equity ratio has a negative and significant effect on the share prices of large trading subsector companies on the Indonesia Stock Exchange.
\end{abstract}

Keywords: debt to equity ratio, return on equity, stock price.

\section{PENDAHULUAN}

Dengan semakin berkembangnya dunia usaha, semakin banyak pula perusahaan yang muncul sehingga menimbulkan persaingan yang ketat. Salah satu bidang usaha yang mengalami perkembangan yang pesat dan persaingan yang ketat dalam usahanya adalah perusahaan retail. Retail merupakan mata rantai yang penting dalam proses distribusi barang dan merupakan mata rantai terakhir dalam suatu proses distribusi. Melalui ritel, suatu produk dapat bertemu langsung dengan penggunanya. Sebagai industri yang menjual produk maupun jasa pelayanan yang telah diberi nilai tambah untuk memenuhi kebutuhan pribadi, keluarga, kelompok atau pemakai akhir. Produk yang dijual kebanyakan adalah pemenuhan dari kebutuhan rumah tangga termasuk Sembilan bahan pokok, oleh karena itu eksitensi retail diindonesia sangat bagus. Persaingan di bidang ini berlangsung cukup ketat antara perusahaan yang satu dengan perusahaan yang lain. Hal ini dapat dilihat dari cukup banyaknya cabang perusahaan retail yang dibuka dan tidak jarang pula yang harus menutup atau memindahkan usahanya. Oleh karena itu, untuk mempertahankan kegiatan usaha dan bersaing dengan perusahaan lain, banyak hal yang dibutuhkan antara lain strategi, ide - ide baru, kepercayaan pelanggan, bahkan modal yang cukup besar. Salah satu cara yang dapat diambil perusahaan untuk memenuhi kebutuhan dana guna mengembangkan perusahaan agar tetap dapat bersaing adalah penjualan saham kepada masyarakat melalui pasar modal. Penjualan saham ataupun obligasi mampu membantu perusahaan menghimpun dana selain dari bank, yang nantinya dana tersebut akan digunakan perusahaan untuk kepentingan investasi tanpa harus menunggu tersedianya dana dari operasi perusahaan, sekaligus pasar modal dapat memberikan peluang bagi investor untuk menginvestasikan 
dananya, dengan tujuan untuk meningkatkan kekayaan dimasa yang akan datang, dengan memperoleh deviden atau capital gain.

Terdapat banyak surat berharga yang diperdagangkan dipasar modal, salah satunya saham. Saham merupakan tanda penyertaan modal seseorang atau pihak (badan usaha) dalam suatu perusahaan (Hermuning, 2012: 78). Dengan keikutsertaan mengeluarkan modal, maka pihak tersebut memiliki klaim atas pendapatan perusahaan. Bagi perusahaan penerbit saham, saham akan meningkatkan nilai ekuitas perusahaan sehingga perusahaan dapat memanfaatkannya sebagai sarana memperoleh pendanaan. Dengan semakin meningkatnya jumlah saham yang ditransaksikan akan dapat mendorong perkembangan pasar modal disuatu negara.

Harga saham suatu perusahaan menjadi tolak ukur investor untuk menanamkan sahamnya. Menurut (Murdhaningsih, dkk. 2018) harga saham merupakan ukuran indeks prestasi perusahaan, yaitu seberapa jauh manajemen dapat mengelola perusahaan atas nama pemegang saham. Menurut (Gereland, dkk. 2017). Harga saham adalah harga suatu saham yang terjadi di pasar bursa pada saat tertentu yang ditentukan oleh pelaku pasar dan ditentukan oleh permintaan dan penawaran saham yang bersangkutan di pasar modal (Jogiyanto, 2013: 48).

Kinerja keuangan perusahaan adalah suatu gambaran tentang kondisi keuangan suatu perusahaan yang dianalisis dengan alat-alat analisis keuangan dan merupakan sarana analisis yang paling mudah dan murah untuk didapat para investor/calon investor. Salah satu komponen yang berhubungan dengan kondisi internal suatu perusahaan adalah kinerja suatu perusahaan yang terdiri dari ROE dan DER dan lain sebagainya (Dewi, dkk. 2018).

Menurut Kasmir (2016: 204) ROE merupakan rasio laba bersih sesudah pajak dengan modal sendiri. Menurut Hery (2015: 230) ROE merupakan rasio yang menujukan seberapa besar kontribusi modal dalam menciptakan laba bersih. ROE merupakan suatu alat analisis untuk mengukur sejauh mana kemampuan perusahaan dalam menghasilkan keuntungan bagi pemilik saham atas modal yang telah mereka investasikan (Tandelilin, 2010).

Menurut Harapan (2010: 303) DER merupakan salah satu rasio leverage yang menggambarkan sejauh mana modal pemilik dapat menutupi utang kepada pihak luar. Menurut Hantono (2015) DER dapat menggambarkan sumber pendanaan perusahaan yang akan berakibat pada reaksi pasar saham, sehingga secara otomatis akan mempengaruhi harga saham. DER merupakan rasio yang digunakan untuk menilai utang dengan ekuitas (Kasmir, 2016: 157).

Penelitian ini diaplikasikan pada perusahaan sub sektor perdagangan besar di Bursa Efek Indonesia tahun 2017-2018. Dalam penelitian awal didapatkan hasil mengenai debt to equity ratio, harga saham, dan return on equity pada perusahaan sub sektor perdagangan besar di Bursa Efek Indonesia. Pada tahun 2017-2018 PT AKBAR Indo Makmur Stimec Tbk mengalami peningkatan ROE sebesar $0,09 \%$ (dari $0,05 \%$ menjadi $0,14 \%$ ). Sedangkan Harga Saham mengalami penurunan sebesar Rp 68 (dari 248 menjadi 180). Hal yang sama juga terjadi pada PT Colorpark Indonesia Tbk ROE mengalami peningkatan sebesar 2,02\% (dari 2,09\% menjadi 4,11\%), sedangkan harga saham mengalami penurunan sebesar $\mathrm{Rp}$ 400 (dari 13,900 menjadi 13,500). hal ini tidak sejalan dengan teori dari Murdhaningsih, dkk (2018) yang menyatakan apabila ROE mengalami peningkatan, maka harga saham juga akan mengalami peningkatan.

Pada tahun 2017-2018 PT Jaya Kontruksi Manggala Pratama Tbk ROE mengalami penurunan sebesar $1,97 \%$ (dari $2,13 \%$ menjadi 0,16\%). Sedangkan Harga Saham mengalami peningkatan sebesar Rp 48 (dari 113 menjadi 161). Hal ini tidak sejalan dengan teori Murdhaningsih, dkk (2018). Dan DER tahun 2017-2018 pada perusahaan PT Jaya Kontruksi Manggala Pratama Tbk mengalami peningkatan sebesar 2,79\% (dari 1,56\% menjadi 4,35\%), sedangkan Harga Saham ikut mengalami peningkatan sebesar Rp 48 (dari 113 menjadi 161). Hal ini tidak sejalan dengan teori dari Jojor Gustmair dan Mariani (2018), 
yang menyatakan bahwa apabila DER mengalami penurunan maka harga saham akan mengalami peningkatan.

Pada uraian pengaruh return on equity dan debt to equity ratio terhadap harga saham terdapat perbedaan pernyataan dan hasil penelitian yang menjadi gap ini menjadi celah untuk mengkaji kembali dengan tujuan untuk memperjelas penelitian sebelumnya, sehingga penulis tertarik melakukan penelitian yang berjudul "Pengaruh Return On Equity dan Debt to Equity Ratio Terhadap Harga Sahampada Perusahaan Sub Sektor Perdagangan Besar yang Terdaftar di Bursa Efek Indonesia".

Berdasarkan uraian latar belakang di atas, maka dapat diambil beberapa rumusan masalah sebagai berikut: (1) Apakah ada pengaruh ROE dan DER terhadap harga saham pada perusahaan sub sektor perdagangan besar yang terdaftar di ursa Efek Indonesia? (2) Apakah ada pengaruh ROE terhadap harga saham pada perusahaan sub sektor perdagangan besar yang terdaftar di bursa Efek Indonesia? (3) Apakah ada pengaruh DER terhadap harga saham pada perusahaan sub sektor perdagangan besar yang terdaftar di bursa Efek Indonesia?

Berdasarkan latar belakang dan rumusan masalah, maka tujuan dari penelitian ini adalah untuk menguji penjelasan yang teruji tentang pengaruh sebagai berikut: (1) Untuk mengetahui pengaruh return on equiy dan debt to equity ratio terhadap Harga Saham pada perusahaan sub sektor perdagangan besar yang terdaftar di bursa Efek Indonesia. (2) Untuk mengetahui pengaruh return on equity terhadap harga saham pada perusahaan sub sektor perdagangan besar yang terdaftar di ursa Efek Indonesia. (3) Untuk mengetahui pengaruh debt to equity ratio terhadap harga saham pada perusahaan sub sektor perdagangan besar yang terdaftar di bursa Efek Indonesia.

\section{KAJIAN PUSTAKA DAN PERUMUSAN HIPOTESIS Harga Saham}

Nilai perusahaan dapat diukur melalui nilai harga saham dipasar, berdasarkan terbentuknya harga saham perusahaan dipasar, yang merupakan refleksi penilaian oleh public terhadap kinerja perusahaan secara riil. Dikatakan secara riil karena terbentuknya harga dipasar merupakan bertemunya titik-titik kestabilan kekuatan permintaan dan titik-titik kestabilan kekuatan penawaran harga yang secara riil terjadi transaksi jualbeli surat berharga dipasar modal antara para penjual (emiten) dan para investor, atau sering disebut sebagai ekuilibrium pasar. Oleh karena itu, dalam teori keuangan pasar modal harga saham di pasar disebut sebagai konsep nilai perusahaan. Proses terbentuknya harga saham di pasar akan sangat tergantung pada kondisi tingkat efisiensi pasar, baik secara informasi maupun secara keputusan, mulai efisiensi bentuk lemah, setengah kuat dan bentuk kuat. (Harmono, 2009: 50).

Menurut Murdhaningsih, dkk (2018) harga saham merupakan ukuran indeks prestasi perusahaan, yaitu seberapa jauh manajemen dapat mengelola perusahaan atas nama pemegang saham. Menurut (Gereland, dkk. 2017). Harga saham adalah harga suatu saham yang terjadi di pasar bursa pada saat tertentu yang ditentukan oleh pelaku pasar dan ditentukan oleh permintaan dan penawaran saham yang bersangkutan di pasar modal (Jogiyanto, 2013: 48). Harga Saham ialah harga yang terbentuk di bursa saham dan umumnya harga saham diperoleh untuk menghitung nilai saham (Kurniawan, 2010: 1).

Berdasarkan pengertian diatas, penulis dapat menyimpulkan bahwa harga saham merupakan penanaman modal atau uang yang dikeluakan didalam suatu perusahaan dan akan memperoleh surat kepemilikan suatu perusahaan yang terbentuk karena adanya interaksi permintaan dan penawaran saham dalam pasar modal.

Rumus harga saham yang digunakan dalam penelitian ini adalah sebagai berikut (Kodrat, 2010: 13).

$$
\text { Harga Saham }=\text { Harga Penutupan (Close) }
$$




\section{Return on Equity (ROE)}

Tujuan akhir yang ingin dicapai suatu perusahaan yang terpenting adalah memperoleh laba atau keuntungan yang maksimal, disamping hal-hal lainnya. Dengan memperoleh laba yang maksimal seperti yang telah ditargetkan, perusahaan dapat berbuat banyak bagi kesejahteraan pemilik, karyawan, serta meningkatkan mutu produk dan melakukan investasi baru. Oleh karena itu, manajemen perusahaan dalam praktiknya dituntut harus mampu untuk memenuhi target yang telah ditetapkan. Artinya besarnya keutungan haruslah dicapai sesuai dengan yang diharapkan dan bukan berarti asal untung. Untuk mengukur tingakat keuntungan suatu perusahaan, digunakan rasio keuntungan atau rasio profitabilitas yang dikenal juga dengan nama rasio rentabilitas. Menurut Kasmir (2016: 196) Profitabilitas merupakan rasio untuk menilai kemampuan perusahaan dalam mencari keuntungan. Rasio ini juga memberikan ukuran tingkat efektivitas manajemen suatu perusahaan.

Menurut Kasmir (2016: 204) ROE merupakan rasio laba bersih sesudah pajak dengan modal sendiri. Menurut Hery (2015: 230) ROE merupakan rasio yang menujukan seberapa besar kontribusi modal dalam menciptakan laba bersih. ROE merupakan suatu alat analisis untuk mengukur sejauh mana kemampuan perusahaan dalam menghasilkan keuntungan bagi pemilik saham atas modal yang telah mereka investasikan (Tandelilin, 2010).

Rasio ini memiliki peranan yang sangat penting bagi investor yang dimana rasio ini digunakan untuk mengetahui seberapa efisien sebuah perusahaan dalam menggunakan dananya untuk menghasilkan laba bagi para pemegang sahamnya.

Menurut Kasmir (2016: 204) rasio ROE ini dihitung dengan rumus sebagai berikut:

$$
\text { Return on Equity }(R O E)=\frac{\text { Earning After Interest and Tax }}{\text { Equity }}
$$

\section{Debt to Equity Ratio (DER)}

Menurut Kasmir (2016: 151), rasio solvabilitas atau laverage ratio merupakan rasio yang digunakan untuk mengukur sejauh mana aktiva perusahaan dibiayai dengan utang. Artinya berapa besar beban utang yang ditanggung perusahaan dibandingkan dengan aktivanya. Dalam arti luas dikatakan bahwa rasio solvabilitas digunakan untuk mengukur kemampuan perusahaan membayar seluruh kewajibannya baik jangka pendek maupun jangka panjang apabila perusahaan dibubarkan.

Menurut Harapan (2010: 303) DER merupakan salah satu rasio leverage yang menggambarkan sejauh mana modal pemilik dapat menutupi utang kepada pihak luar. Menurut (Hantono. 2015) DER dapat menggambarkan sumber pendanaan perusahaan yang akan berakibat pada reaksi pasar saham, sehingga secara otomatis akan mempengaruhi harga saham. DER merupakan rasio yang digunakan untuk menilai utang dengan ekuitas (Kasmir, 2016: 157).

Rasio ini memiliki peranan yang sangat penting bagi perusahaan yang dimana rasio ini berguna untuk mengetahui jumlah dana yang disediakan peminjam (kreditor) dengan pemilik perusahaan. Dengan kata lain, rasio ini berfungsi untuk mengetahui setiap rupiah modal sendiri yang dijadikan untuk jaminan utang.

Menurut Kasmir (2016: 158), DER diukur dengan rumus sebagai berikut:

Debt to Equity ratio $(D E R)=\frac{\text { Total Utang (debt) }}{\text { Ekuitas (Equity) }}$

\section{Hubungan Return on Equity (ROE) dan Debt to Equity Ratio terhadap Harga Saham}

Hasil penelitian Nurmala dan Lucian (2017) menyatakan bahawa secara bersamaan ROE dan DER berpengaruh signifikan. Hal ini merupakan salah satu indikator yang dilihat investor untuk mengambil keputusandalam berinvestasi karena ROE dan DER mempengaruhi terhadap naik turunnya harga saham.Ini sejalah dengan penelitian yang dilakukan oleh Munira, dkk (2018). 
$\mathrm{H}_{1}$ :Ada pengaruh return on equity dan debt to equity ratio terhadap harga saham pada perusahaan sub sektor perdagangan besar di Bursa Efek Indonesia.

\section{Hubungan Return on Equity (ROE) terhadap Harga Saham}

ROE merupakan ukuran kinerja perusahaan ditinjau dari segi profibilitasnya ROE yang semakin meningkat, maka investor semakin tertarik untuk menanamkan dananya ke dalam perusahaan, sehingga harga saham cenderung meningkat (Murdhaningsih, dkk 2018). Ini sejalan dengan penelitian yang dilakukan oleh Nurmala dan Lucian (2017) hasil penelitiannya menunjukkan bahwa ROE memiliki pengaruh signifikan terhadap harga saham.

$\mathrm{H}_{2}$ :Ada pengaruh return on equity terhadap harga saham pada perusahaan sub sektor perdagangan besar di Bursa Efek Indonesia.

\section{Hubungan Debt to Equity Ratio (DER) terhadap Harga Saham}

DER merupakan rasio untuk mengukur kemampuan perusahaan dalam menjamin utang dengan modal sendiri. Nilai DER sangat diperhatikan oleh para investor karena dapat menunjukan komposisi pendanaan dalam membiayai aktivitas operasional perusahaan atau memanfaatkan hutang-hutangnya. Semakin rendah DER menandakan modal yang digunakan dalam operasional perusahaan semakin besar, sehingga resiko yang ditanggung investor juga akan semakin kecil dan mampu meningkatkan harga saham. Sebaliknya, semakin besar DER menunjukan struktur modal lebih memanfaatkan hutang sehingga beban perusahaan dan ketergantungan perusahaan terhadap pihak luar sehingga tingkat resikonya menjadi semakin besar. Hal ini akan berdampak keuntungan yang diperoleh akan menurun yang membuat minat para investor menurun dan harga saham di bursa ikut menurun, Karena laba yang diperoleh cenderung digunakan untuk membayar hutang dibandingkan membayar deviden (Gustmair dan Mariani, 2018). Teori ini sejalan dengan penelitian yang telah dilakukan oleh Munira, dkk (2018). Yang menyatakan bahwa debt to equity ratio berpengaruh signifikan terhadap harga saham.

$\mathrm{H}_{3}$ :Ada pengaruh debt to equity ratio terhadap harga saham pada perusahaan sub sektor perdagangan besar di Bursa Efek Indonesia.

\section{METODE}

Desain penelitian ini merupakan kuantitatif kausal yaitu penelitian yang menekankan pada pengujian teori-teori melalui pengukuran variabel-variabel penelitian dengan angka dan melakukan analisis data dengan prosedur statistik. Pendekatan kuantitatif kausan merupakan penelitian pendekatan ilmiah terhadap pengambilan keputusan manajerial dan ekonomi yang bertujuan untuk mendapatkan bukti hubungan sebab akibat atau pengaruh dari variabel-variabel penelitian. Desain kausalitas dapat dilakukan dengan langkah-langkah sebagaiberikut: (1) merumuskan masalah, (2) landasan teori, (3) merumuskan hipotesis, (4) melakukan penelitian, (5) mengumpulkan data dan analisis data, serta (6) menyusun laporan dan menyimpulkan.

Variabel bebas yang digunakan pada penelitian ini meliputi: return on equity $\left(\mathrm{X}_{1}\right)$, dan debt to equity ratio $\left(\mathrm{X}_{2}\right)$. Sedangkan variabel terikat yang digunakan adalah harga saham (Y). Penelitian ini dilakukan pada perusahaan sub sektor perdagangan besar yang terdaftar di Bursa Efek Indonesia. Subjek dalam penelitian ini adalah perusahaan sub sektor perdagangan besar di Bursa Efek Indonesia. Sedangkan yang menjadi objek dalam penelitian ini adalah return on equity (ROE), debt to equity ratio (DER), dan harga saham. Menurut Sugiyono (2017: 81), sampel adalah bagian dari jumlah dan karaktristik yang dimiliki oleh populasi tersebut. Teknik sampel yang digunakan dalam penelitian ini adalah purposive sampling, dimana teknik ini merupakan teknik penentuan sampel dalam penelitian ini adalah 1) Perusahaan Sub Sektor Perdagangan Besar yang masih terdaftar di Bursa Efek Indonesia tahun 2017-2018. 2) Perusahaan Sub Sektor Perdagangan Besar yang mempublikasikan laporan keuangan secara lengkap di Bursa Efek Indonesia tahun 20172018. 3) Perusahaan Sub Sektor Perdagangan Besar yang menyediakan data yang terkait dengan variabel peneliti. 
Berdasarkan kriteria diatas, maka didapatkan sampel sebanyak 15 perusahaan, karena terdapat beberapa perusahaan yang tidak memenuhi syarat yaitu tidak menyediakan data yang terkait dengan variabel peneliti dan tidak mempublikasikan laporan keuangan secara lengkap di Bursa Efek Indonesia tahun 2017-2018. Untuk memperoleh data di lapangan maka perlu dilakukan pengumpulan data. Teknik yang digunakan penulis dalam penelitian ini yaitu menggunakan pencatatan dokumen. Data yang diperoleh merupakan data sekunder. Teknik pengumpulan data ini merupakan pengumpulan data dengan cara mencatat data yang berhubungan dengan masalah yang akan diteliti dari dokumendokumen yang dimiliki perusahaan. Melalui penelitian ini diharapkan akan memperoleh data mengenai return on equity, debt to equity ratio dan harga saham, serta informasi-informasi lain yang diperlukan.

Teknik analisis data dalam penelitian ini, yaitu dengan menggunakan teknik analisis regresi linear berganda. Adapun pengolahan data penelitian ini dibantu dengan program komputer Statistical Package for Social Science (SPSS) Versi 22.0. Sebelum data diolah ke analisisregresi linier berganda, terlebih dahulu diuji dengan pengujian asumsi klasik, karena syarat untuk analisis regresi linier berganda adalah bebas dari asumsi-asumsi klasik. Uji asumsi klasik meliputi:

1. Uji Normalitas

Uji Normalitas ini bertujuan untuk menguji apakah dalam suatu model regresi linier variabel pengganggu atau residul memiliki distribusi normal. Model regresi yang baik adalah memiliki distribusi data normal atau mendekati normal. Untuk mengetahui normal atau tidak distribusi data dapat menggunakan analisis grafik dan uji statistik (Ghozali, 2011). Adapun dasar pengambilan keputusan memenuhi normalitas atau tidak, yaitu sebagai berikut:

a) Jika data menyebar di sekitar garis diagonal dan mengikuti arah garis diagonal atau grafik histogramnya menunjukkan pola distribusi normal, maka model regresi memenuhi asumsi normalitas.

b) Jika data yang menyebar jauh dari garis diagonalnya dan/ atau tidak mengikuti garis diagonal atau grafik histogram tidak menunjukkan pola distribusi normal, maka model regresi tidak memenuhi asumsi normalitas.

Kriteria yang digunakan dalam tes ini adalah dengan cara membandingkan antara tingkat alpha yang digunakan, dimana data tersebut bisa dikatakan berdistribusi normal apabila sig > alpha. Data populasi dikatakan normal jika koefisien Asym Sig (2 - tield) lebih besar dari 0,05

2. Uji Multikolinearitas

Uji multikolinearitas bertujuan untuk menguji apakah dalam model regresi ditemukan adanya kolerasi atar variabel bebas atau tidak (Ghozali, 2005). Model regresi yang baik seharusnya tidak terjadi kolerasi diantara variabel bebas. Multikolinearitas dapat dilihat dari nilai tolerance dan nilai Variance Inflation Factors (VIF). Nilai yang umum dipakai untuk menunjukan adanya multikolinearitas adalah nilai tolerance 0,10 atau sama dengan VIF 10 (Ghozali, 2005). Dalam penelitian ini digunakan nilai VIF sebagai indicator ada tidaknya multikolinearitas diantara variabel bebas. Dasar pengambilan keputusan adalah sebagai berikut.

a. Jika nilai VIF < 10 maka, dapat disimpulkan bahwa tidak ada multikolinearitas atar variabel bebas dalam model regresi.

b. Jika nilai VIF > 10 maka, dapat disimpulkan bahwa ada multikolinearitas atar variabel bebas dalam model regresi.

3. Uji Heteroskedastisitas

Menurut Ghozali (2011), uji heteroskedastisitas digunakan untuk melihat ketidaksamaan varian dari residual pengamatan yang satu ke pengamatan lainnya. Apabila timbul ketidaksamaan varian, maka terdapat masalah heteroskedastisitas. Model regresi yang baik adalah yang sifatnya homokedastisitas atau tidak terjadi heteroskedastisitas. Uji heteroskedastisitas dalam peneliian ini dilakukan dengan melihat grafik plots. Model regresi tidak terjadi heteroskedastisitas apabila harga saham signifikansinya diatas tingkat kepercayaan $5 \%$. 


\section{Uji Autokolerasi}

Uji autokolerasi digunakan untuk mengetahui ada atau tidaknya kolerasi antara kesalahan pengganggu pada periode t dengan kesalahan pengganggu pada t-1 (Ghozali, 2011: 110). Menurut Danang Sunyoto (2007: 104) persyaratan yang harus terpenuhi adalah tidak adanya autokolerasi dalam model regresi. Adanya autokolerasi akan mengakibatkan penaksiran dengan kuadrat terkecil akan sangat sensitif terhadap fluktuasi sampel dan penaksir-penaksirannya tidak efisien lagi. Untuk mengetahui adanya autokolerasi akan dilakukan Uji Durbin Waston. Menurut Suliyanto (2005), kriteria yang digunakan adalah dengan melihat besarnya Durbin Waston (D-W) sebagai berikut:

a) Jika angka D-W dibawah -2 berarti ada autokolerasi positif.

b) Jika angka D-W di antara -2 sampai +2 berarti tidak ada autokolerasi.

c) Jika angka D-W di atas +2 berarti ada autokolerasi negative.

\section{HASIL DAN PEMBAHASAN}

\section{HASIL}

Model analisis yang digunakan pada penelitian ini yaitu regresi linier berganda. Pengujian dilakukan dengan bantuan SPSS 22.0. Maka dapat diperoleh struktur hubungan pengaruh return on equity dan debt to equity ratio terhadap harga saham pada perusahaan sub sektor perdagangan besar di Bursa Efek Indonesia dapat dilihat pada Gambar 1

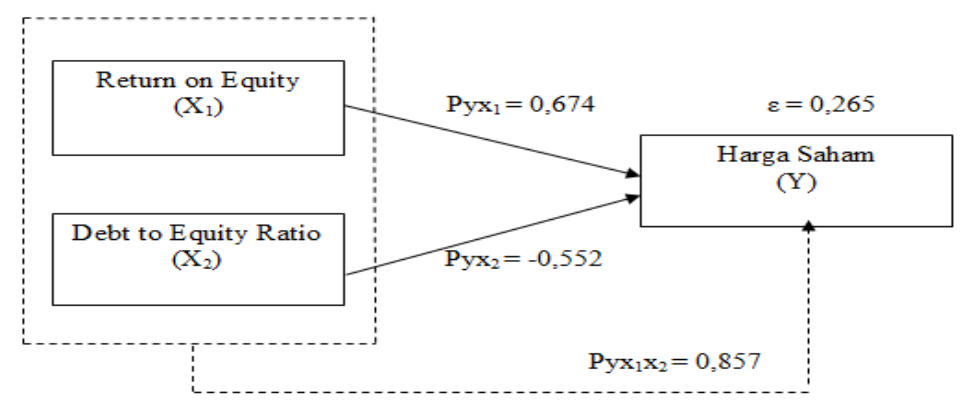

Gambar 1. Struktur hubungan pengaruh antara ROE $\left(\mathrm{X}_{1}\right)$ dan DER $\left(\mathrm{X}_{2}\right)$ terhadap harga saham (Y).

Determinasi digunakan untuk mengukur seberapa besar nilai sumbangan yang diberikan oleh variabel bebas untuk variabel terikat. pada penelitian ini diperoleh nilai $\mathrm{R}^{2}$ sebesar 0,735 (73,5\%). Hasil ini menunjukan bahwa harga saham dipengaruhi oleh return on equity dan debt to equity ratio sebesar 0,735 (73,5\%), sedangkan 0,265 (26,5\%) dipengaruhi oleh variabel lain yang tidak diteliti dalam penelitian ini.

Pada penelitian ini analisis regresi linier berganda menunjukan $\operatorname{Ryx}_{1} \mathrm{x}_{2}=0,857$ dengan $p$-value $0,000<\alpha 0,05$, sehingga keputusan yang diambil adalah menolak Ho. Artinya ada pengaruh signifikan return on equity $\left(\mathrm{X}_{1}\right)$ dan debt to equity ratio $\left(\mathrm{X}_{2}\right)$ terhadap harga saham $(Y)$ pada perusahaan sub sektor perdagangan besar di Bursa Efek Indonesia.

Pada penelitian ini analisis regresi linier berganda menunjukan $\operatorname{Pyx}_{1}=0,647$ dengan $p$-value $0,000<\alpha 0,05$, sehingga keputusan yang diambil adalah menolak Ho. Artinya ada pengaruh positif dan signifikan return on equity $\left(\mathrm{X}_{1}\right)$ terhadap harga saham ( $\mathrm{Y}$ ) pada perusahaan sub sektor perdagangan besar di Bursa Efek Indonesia. Besar sumbangan pengaruh return on equity terhadap harga saham adalah 0,454 (45,4\%).

Analisis regresi linier berganda menunjukan $\mathrm{Pyx}_{2}=-0,552$ dengan $p$-value $0,002<\alpha$ 0,05 , sehingga keputusan yang diambil adalah menolah Ho. Artinya ada pengaruh negatif signifikan debt to equity ratio terhadap harga saham. Adapun besar sumbangan pengaruh debt to equity ratio terhadap harga saham adalah $0,305(30,5 \%)$.

\section{Pembahasan}

Hasil penelitian menujukan bahwa secara simultan variabel bebas yaitu ROE dan DER berpengaruh signifikan terhadap harga saham pada perusahaan sub sektor 
perdagangan besar yang terdaftar di Bursa Efek Indonesia. Hasil ini menujukan bahwa pada saat ROE dan DER mengalami kenaikan atau penurunan maka secara signifikan akan berpengaruh terhadap harga saham pada perusahaan sub sektor perdagangan besar yang terdaftar di Bursa Efek Indonesia. Hasil penelitian ini didukung oleh penelitian dari Alfiah dan Diyani (2017), yang menyatakan bahwa ROE dan DER berpengaruh secara bersama-sama terhadap harga saham.

Hasil penelitian yang telah dilakukan menunjukan bahwa ada pengaruh positif dan signifikan ROE terhadap harga saham pada perusahaan sub sektor perdagangan besar yang terdaftar di Bursa Efek Indonesia. ROE merupakan suatu alat analisis untuk mengukur sejauh mana kemampuan perusahaan dalam menghasilkan keuntungan bagi pemilik saham atas modal yang telah mereka investasikan (Tandelilin, 2010). Semakin tinggi ROE, maka investor semakin tertarik untuk menanamkan dananya ke dalam perusahaan, sehingga harga saham cenderung meningkat (Murdhaningsih, dkk 2018). Dan penelitian ini didukung oleh penelitian sebelumnya yang dilakukan oleh Gultom, dkk (2019), yang menemukan bahwa ada pengaruh positif dan signifikan return on equity terhadap harga saham.

Debt to equity ratio digunakan untuk mengukur sejauh mana perusahaan dalam menjamin utang dengan modal sendiri. Semakin rendah debt to equity menandakan modal yang digunakan dalam operasional perusahaan semakin besar, sehingga resiko yang ditanggung investor juga semakin kecil dan mampu meningkatkan harga saham (Gustmair \& Mariani, 2018). Dalam penelitian ini debt to equity ratio berpengaruh negatif signifikan terhadap harga saham pada perusahaan sub sektor perdagangan besar yang terdaftar di Bursa Efek Indonesia. Hasil penelitian ini sejalan dengan penelitian yang dilakukan oleh Ramadhani \& Pustikaningsih (2017), yang menyatakan bahwa DER berpengaruh negative dan signifikan terhadap harga saham.

\section{SIMPULAN DAN SARAN \\ Simpulan}

Berdasarkan hasil penelitian dan pembahasan yang telah diperoleh, maka simpulan dari penelitian ini adalah sebagai berikut. (1) ROE dan DER berpengaruh signifikan secara bersama-sama terhadap harga saham pada perusahaan sub sektor perdagangan besar yang terdaftar di Bursa Efek Indonesia tahun 2017-2018. (2) ROE berpengaruh positif dan signifikan secara parsial terhadap harga saham pada perusahaan sub sektor perdagangan besar yang terdaftar di Bursa Efek Indonesia tahun 2017-2018. (3) DER berpengaruh negatif dan signifikan terhadap harga saham pada perusahaan sub sektor perdagangan besar yang terdaftar di Bursa Efek Indonesia tahun 2017-2018.

\section{Saran}

Hasil penelitian ini diharapkan dapat digunakan sebagai informasi bagi perusahaan sub sektor perdagangan besar di Bursa Efek Indonesia dalam mengambil keputusan supaya perusahaan lebih mampu meningkatkan harga sahamnya. Mengingat di beberapa perusahaan sub sektor perdagangan besar di Bursa Efek Indonesia pada tahun 2017-2018 mengalami penurunan harga saham, maka perusahaan perlu memperhatikan return on equity dan debt to equity ratio supaya kedepannya mampu meminimalisir terjadinya penurunan harga saham pada perusahaan sub sektor perdagangan besar di Bursa Efek Indonesia.

Bagi peneliti selanjutnya diharapkan menambah rentang waktu penelitian karena penelitian ini hanya menggunakan periode pengamatan selama 2 tahun yaitu 2017-2018. Dengan penggunaan rentang waktu penelitian yang lebih lama sehinggaakan mendapatkan hasil penelitian yang lebih baik, kemudian peneliti selanjutnya diharapkan untuk menambah variabel lain yang mempengaruhi harga saham. karena variabel yang digunakan pada penelitian ini masih terbatas.

\section{DAFTAR PUSTAKA}

Alfiah, Nurmala dan Ari Diyani Lucian, 2017. Pengaruh ROE dan DER terhadap Harga Saham pada Sektor Perdagangan Eceran. Bisnis Terapan. Vol. 01, No. 02. 25974157. 
Atmaja, Lukas Setia. 2008. Manajemen Keungan. Yogyakarta: Andi Yogyakarta

Bastian, Indra. 2006. Akuntansi Sektor Publik: Suatu Pengantar, Erlangga, Jakarta.

Brigham, E.F. \& Houston, J.F. 2010. Dasar-dasar Manajemen Keuangan Buku 1, Edisi 11. Jakarta: Selemba Empat.

Dewi, dkk. 2018. Pengaruh Return On Assets dan Economic Value Added Terhadap Harga Saham Perusahaan Yang Terdaftar dalam Jakarta Islamic Index Periode 2014-2016. Jurnal Riset Akuntansi. 1(1). 98.

Edsel, Gereland, dkk. 2017. Pengaruh Return on Asset, Return on Equity, Net Profit Margin dan Earning Per Share terhadap Harga Saham Perusahaan yang tergabung dalam Indeks LQ 45 di Bursa Efek Indonesia. Jurnal EMBA. Vol. 5, No 1. 2303-1174.

Fahmi, Irham. 2012. Pengantar Pasar Modal. Bandung: Alfabeta.

Ghozali, Imam. 2006. Aplikasi Analisis Multivariate dengan Program SPSS Cetakan ke - IV, Badan Penerbit Unversitas Diponegoro, Semarang.

Ghozali, Imam. 2011. Aplikasi Analisis Multivariate. Semarang: Badan Penerbit Universitas Diponegoro.

Ghozali, Imam. 2015. Aplikasi Analisis Multivariate dengan SPSS, Badan Penerbit Universitas Diponogoro, Semarang.

Gustmainar, Jojor dan Mariani. 2018. Analisis Of The Effect Of Current Ratio, Debt To Equity Ratio, Gross Profit Margin, Return On Invesment, And Earning Per Share On Stock Prices At LQ 45. BILANCIA. Vol 2. No 4. 2549-5704.

Hantono. 2015. Pengaruh Current Ratio Dan Debt To Equity Ratio Terhadap Profitabilitas Pada Perusahaan Manufaktur Sektor Logam Dan Sejenisnya Yang Terdaftar Di Bursa Efek Indonesia Periode 2009-2013. Jurnal Wira Ekonomi Mikroskill. 5(1): 12-29.

Harapan, S, S. 2010. Analisis Kritis Atas Laporan Keuangan. Jakarta: PT. Raja Grafindo Persada.

Harmono. 2009. Manajemen Keuangan Berbasis Balanced Scorecard Pendekatan Teori, Kasus dan Riset Bisnis. Jakarta: PT Bumi Aksara.

Hermuning, Sri. 2012. Pengantar Pasar Modal Indonesia Edisi 1. UPP STIM YKPN: Yogyakarta.

Hery. 2015. Analisis Laporan Keuangan. Yogyakarta: CAPS.

Jogiyanto, Hartono. 2013. Teori Portofolio dan Analisa Investasi. Yogyakarta: BPFE.

Kasmir. 2016. Analisis Laporan Keuangan. Cetakan Kesembilan. Jakarta: PT Raja Grafindo Persada.

Kennedy \& Ataribaba. 2019. Pengaruh ROR dan DER terhadap PER untuk Perusahaan Property di BEI Periode 2010-2016. Jurnal Manajemen Bisnis. Vol 6. No 1. 26211971.

Kurniawan, Albert. 2014. Metode riset untuk Ekonomi \& Bisnis (Teori, Konsep \& praktik penelitian bisnis dilengkapi perhitungan pengolah data IBM SPSS 22.0). ALFABETA: Bandung.

Kodrat, David Sukardi \& Kurniawan Indonanjaya. 2010. Manajemen Investasi Pendekatan dan Fundamental Untuk Analisis Saham. Yogyakarta: Graha IImu.

Munira, dkk. 2018. Pengaruh ROE dan DER terhadap Harga Saham Perusahaan Kertas di Bursa Efek Indonesia. Applied Business and Economics. Vol 4. No 3. 191-205.

Murdhaningsih, dkk. 2018. Analisis Pengaruh Debt to Equity Ratio, Return on Equity, Current Ratio, Operating Profit Margin dan Infalasi tergadap Harga Saham. JURNAL EKOBISMAN. Vol 3, No 2. 2597-9302.

Ramdhani dan Pustikaningsih. 2017. Pengaruh Debt to Equity Ratio, Return on Equity dan Net Profit Margin terhadap Harga Saham pada Perusahaan Sektor Pertambangan yang Terdaftar di Bursa Efek Indonesia. Jurnal Profita. Vol 2, No 3.

Riahi, Ahmed \& Belkaoui. 2004. Accounting Theory. New York: Cengage Learning EMEA.

Soemarso, S.R. 2008. Akuntansi Suatu Pengantar: Buku Satu Edisi. Jakarta: Salemba Empat

Sugiyono. 2017. Metode Penelitian Kuantitatif, Kualitatif dan R\&D. Bandung: Alfabeta. 
Sunyoto. D. 2007. Analisis Regresi dan Kolerasi Bivariat Ringkasan dan Kasus. Yogyakarta: Amara Books.

Suliyanto, 2005. Analisis Data Dalam Aplikasi Pemasaran. Bogor: Ghalia Indonesia.

Sutrisno. 2009. Manajemen Keuangan Teori, Konsep dan Aplikasi, Edisi Pertama, Cetakan Ketujuh. Penerbit Ekonisia. Yogyakarta.

Tandelilin, Eduardus. 2010. Analisis Investasi dan Manajemen Portofolio. Edisi Pertama. Yogyakarta: BPFE.

Trifena, Suriadi dan Indra Widjaja. 2019. Pengaruh Earning Per Share, Debt to Equity Ratio, Price Earning Ratio, Return on Equity terhadap Harga Saham perusahaan Makanan dan Minuman di BEI. JURNAL MANAJEMEN BISNIS DAN KEWIRAUSAHAAN. Vol 3, No 2. 24-23.

Widiatmojo, Sawidji. 2005. Cara Sehat Investasi di Pasar Modal. Jakarta: Media Komputidon. 